\title{
On Beauty, Taste and Other Aesthetic Theories of David Hume*
}

\author{
KONG Zhong-min \\ South China Business College of Guangdong University of Foreign Studies (GDUFS), Guangzhou, China
}

\begin{abstract}
In this paper, David Hume's research on the essence and causes of beauty, the standard of taste, and aesthetic effect Of Tragedy will be discussed to explore his aesthetic principles and philosophy of art. Hume points out that beauty, with the power to produce pleasure as its essence, is an order and construction of parts being fitted to the soul. Hume discusses the diversity and universality of taste and his attempt to find the standard of taste. The aesthetic effect Of Tragedy in the eyes of Hume is also introduced. Hume's aesthetic theory is closely connected to his moral philosophy and theories of human thought and emotion following the English empirical tradition of experience and observations.
\end{abstract}

Keywords: David Hume, essence of beauty, standard of taste, tragedy

\section{Introduction}

In the 18th century, Scottish empiricist David Hume sought to develop more fully Locke's cautious empiricism by applying the scientific methods of observation to a study of human nature. Hume develops his aesthetic theories based on English empirical tradition of experience and observations, which shows an opposite standpoint to the French Rationalism represented by Descartes. However, his aesthetic theory, which is closely connected to his moral philosophy and theories of human thought and emotion, received limited attention until the second half of the 20th century. Hume's ideas about aesthetics and the theory of art are spread throughout his works, particularly connected with his two essays Of the Standard of Taste (1757) and Of Tragedy (1757).

\section{Hume's Research on the Essence and Causes of Beauty}

Hume regards the natural capacity of taste as fundamental to the human ability to make aesthetic judgments. From Hume's point of view, "beauty" cannot be defined, but only discerned by "a taste or sensation". He meditates on the essence and causes of beauty, which constitute the key points of his aesthetic thinking. In $A$ Treatise of Human Nature, Hume claims that if we consider all the hypotheses to explain the difference between beauty and deformity, we will find that "beauty is such an order and construction of parts, as either by the primary constitution of our nature, by custom, or by caprice, is fitted to give a pleasure and satisfaction to the soul" (Hume, 1985). Hume holds that it is the distinguishing character of beauty, and constitutes the whole difference between beauty and deformity; then he proceeds to claim that "pleasure and pain are not only necessary attendants of

\footnotetext{
* Acknowledgements: This paper is funded by the Key Program of the English Language and Literature of Guangdong Province, 2016.

KONG Zhong-min, MA, Lecturer, College English Department, South China Business College of Guangdong University of Foreign Studies (GDUFS), Guangzhou, China.
} 
beauty and deformity, but constitute their very essence” (Hume, 1985). There are two points remarkable in this statement:

1. Hume confirms that the essence of beauty consists in pleasure, which distinguishes beauty from deformity; that is to say, he equates beauty with the pleasant sensation of the appreciator;

2. As to the major causes of pleasure, Hume thinks they can be both objective as a structure of different parts and subjective as the basic constitution of our nature, custom, or caprice.

The pleasure is produced by the natural capacity of the object being fitted to the mind. The two factors are equally important in producing beauty.

Hume thinks that the "taste or sensation", in essence, refers to the feelings of pleasure and pain. Beauty, whether it is natural or moral, has a power to produce pleasure. Pleasure always accompanies beauty, so the power to produce pleasure is the essence of beauty. From the original structure of the internal fabric, some particular forms or qualities are, according to Hume, calculated to please, and others to displease. In Of the Standard of Taste, Hume clearly depicts that "beauty is no quality in things themselves; it exists merely in the mind which contemplates them” (Lenz, 1982). From this, we can see the importance Hume attaches to the subjectivity of beauty and the determination of mind on producing beauty. There is no doubt that Hume is considered as subjectivist in aesthetics. In The Sceptic, he asserts again that "there is nothing, in itself, valuable or despicable, beautiful or deformed; but that these attributes arise from the particular constitution and fabric of human sentiment and affection”.

What fully illustrates Hume's statement on the essence of beauty is his treatise An Inquiry Concerning the Principles of Morals, "Euclid has fully explained all the qualities of the circle; but has not in any proposition said a word of its beauty. The reason is evident. The beauty is not a quality of the circle. It lies not in any part of the line, whose parts are equally distant from a common centre. It is only the effect which that figure produces upon the mind, whose peculiar fabric of structure renders it susceptible of such sentiments. In vain would you look for it in the circle, or seek it, either by your senses or by mathematical reasoning, in all the properties of that figure” (Hume, 1957). Then, Hume proceeded to make a distinction between taste and cognition. All natural beauty depends on the proportion, relation, and position of parts, but it would be absurd thence to infer that the perception of beauty consists wholly in the perception of relations, and was performed entirely by the understanding or intellectual faculties. "In all the sciences, our mind from the known relations investigates the unknown. But in all decisions of taste or external beauty, all the relations are beforehand obvious to the eye; and we thence proceed to feel a sentiment of complacency or disgust, according to the nature of the object, and disposition of our organs" (Hume, 1957).

In his discussion of beauty, David Hume emphasizes certain qualities of the object which are themselves agreeable. In other words, he advocates that there should be certain qualities in the object necessary to arouse pleasure in the appreciator; moreover, this very ability of the object itself may become the essence of beauty.

Though it be certain that beauty and deformity, more than sweet and bitter, are not qualities in objects, but belong entirely to the sentiment, internal or external, it must be allowed, that there are certain qualities in objects which are fitted by nature to produce those particular feelings. (Hume, 1957) 
Not only does Hume mention that the order, structure, shape, proportion, relation, and position as the conditions and qualities of the object to produce beauty, but also the convenience and utility is indeed a great part of the beauty. Based on the above research, Hume claims that "beauty is nothing but a form, which produces pleasure, as deformity is a structure of parts, which conveys pain; and since the power of producing pain and pleasure make in this manner the essence of beauty and deformity, all the effects of these qualities must be derived from the sensation". What is called "the power of producing pleasure" is just that certain quality of the object which is fitted to the mind and makes it pleasant. Here, what Hume emphasizes is the objective factors in producing beauty; and this, risen immediately after his statement that "pleasure and pain constitutes the essence of beauty and deformity", ends up seemingly contradictory to the latter.

However, that is not true. Hume holds that the essence of beauty lies in the feeling of pleasure produced in human mind. It is this sensation that determines the beauty or deformity of the object, in other words, it is not beauty that arouses aesthetic feeling, but that aesthetic feeling produces beauty. Beauty is affixed to the object by the aesthetic subject, and the sensation depends on the original structure of inner mind for existence. Therefore, it is the mind and sensation that is the very determiner of beauty. It is no wonder that Hume, a subjectivist in aesthetics, insists the only real existence of perception, and the skepticism and agnosticism in the real cause of perception.

\section{Hume's Discussion on the Standard of Taste}

Since beauty exists merely in the mind which contemplates them and particular forms or qualities are calculated to please, so what are these particular forms or qualities of the mind?

Hume discusses the standard of taste mainly in Of the Standard of Taste and Of the Delicacy of Taste and Passion. Of the Standard of Taste is a rich contribution to the then-emerging discipline of what is now called aesthetics. This complex essay contains a lucid statement of Hume's views on what constitutes "just criticism”.

According to Hume, human nature is composed of reason and sentiment, the former relates to knowledge and understanding, while the latter is of moral and taste. Taste is a different concept from reason.

Thus, the distinct boundaries and offices of reason and of taste are easily ascertained. The former conveys the knowledge of truth and falsehood: The latter gives the sentiment of beauty and deformity, vice and virtue. The one discovers objects as they really stand in nature, without addition or diminution: The other has a productive faculty and gilding or staining all natural objects with the colors, borrowed from internal sentiment, raises in a manner a new creation. (Lenz, 1982)

Here sums up three major characteristics of the taste: emotionality, subjectivity, and creativity.

Based on the distinction between taste and reason, Hume affirms the variety and relativity of taste. However, he still attempts to seek a standard for taste, a rule by which the various sentiments of men can be reconciled, which constitutes the main problem to be discussed in Of the Standard of Taste.

Hume holds that all the general rules of art are founded only on experience, and on the observation of the common sentiments of human nature. Various and capricious are the tastes of people, but the great writers as Homer and their great works are admired in different ages and nations. A real genius, the longer his works endure and the wider they are spread, the more sincere is the admiration which he meets with. 
It appears, then, that amidst all the variety and caprice of taste, there are certain general principles of approbation or blame, whose influence a careful eye may trace in all operations of the mind. Some particular forms or qualities, from the original structure of the internal fabric are calculated to please, and others to displease. (Lenz, 1982)

Hume claims that reactions to the same aesthetic object varies from person to person and thus, aesthetic experiences will be quite different. There must exist certain critics best able to make judgments.

After affirming the existence of general rules and standard of taste, Hume puts forward two questions:

1. Why do people often sever from this general rule and standard of taste so as to make different judgment or false taste?

2. How to ascertain and find this standard of taste?

The first question is discussed in four aspects: defective state of the organ; the want of delicacy of imagination; the influence of prejudice; and the want of good sense. As to the causes of people's variety of taste and deviation from the standard of taste, Hume's above explanation is based on the review and psychoanalysis of human aesthetic experience. It is valuable as to guide the study of the rule of aesthetic mentality and to improve men's aesthetic ability. Moreover, it answers the question of what qualities should people possess in order to have the just criticism on beauty, and thus, paves the way for the ascertainment and search Of the Standard of Taste.

A true judge in the finer arts is observed, even during the most polished ages, to be so rare character: Strong sense, united to delicate sentiment, improved by practice, perfected by comparison, and cleared of all prejudice, can alone entitle critics to this valuable character; and the joint verdict of such, wherever they are to be found, is the true standard of taste and beauty. (Lenz, 1982)

Here, Hume gives an explicit answer on how to ascertain the standard of taste, and he thinks that the general and just standard can be used to reconcile the various and different tastes of men, confirming one sentiment and condemning another.

In summary, Hume admits the variety and diversity of taste, but he does not get into relativism. On the one hand, he tries to ascertain the general principle and standard of taste to harmonize different tastes and enhance people's artistic percipiency; on the other hand, he admits the existence of diversity in standard. His research and viewpoint on the relativity and absoluteness of taste reach the highest level of that time.

\section{Hume's Viewpoint on the Aesthetic Effect Of Tragedy}

Of Tragedy addresses the question of why humans enjoy tragic drama from the perspective of aesthetics. Hume proposes to explain the way spectators find pleasure in sorrow, terror, anxiety, and other naturally disagreeable emotions depicted in a tragedy (Green \& Grose, 1874, p. 258).

The discussion begins with two explanations given by L'Abbe Dubos (1670-1742, French diplomat, archaeologist, and historian) and Monsieur Fontenelle (1657-1757, French academician, essayist, tradian, and poet). Dubos holds that tragedy can stimulate men and rid them of languish and indolence; the imagination of great loss or gain affects the spectator with sympathy, and severs him as a momentary entertainment. Hume argues that this explanation simply cannot hold water. Were the same object of distress, which pleases men in tragedy, really set before them, it would bring nothing but unfeigned uneasiness. Monsieur Fontenelle puts forward another explanation: 
There lurks at the bottom a certain idea of falsehood in the whole of what we see. This idea, though weak and disguised, suffices to diminish the pain which we suffer from the misfortunes of those whom we love, and to reduce that affliction to such a pitch as converts it into a pleasure.

Hume cites an example to argue its limitation-In the Epilogues of Cicero, as to the pathetic description of the butchery made by Verres of the Sicilian captains, here the sorrow of the spectator could not be softened by fiction; for the audience were convinced of the reality of every circumstance.

After all, what is it that makes pleasure grow out of uneasiness?

"This extraordinary effect proceeds from that very eloquence with which the melancholy scene is represented" (Stroud, 1977), answers Hume. The force of imagination, the energy of expression, the power of numbers, the charms of imitation, the beauties of imagination or expression, if joined to passion, diffuse the highest satisfaction among the audience. "The soul being at the same time roused by passion and charmed by eloquence feels on the whole a strong movement, which is altogether delightful” (Stroud, 1977).

According to Hume, when the same object produces different passions, even those "of a contrary nature", then the subordinate passion can be "converted" into the predominant (Green \& Grose, 1874, p. 262). So, beauty arises when imagination and pleasure is predominant over sorrow or pain; only in this condition, will the latter, being now subordinate, be converted into the former. He cites an Italian phrase Dolce peccante (sweet failings) as an example. It embodies two basic elements of love- “jealousy" and "absence”, which are supposed to be essential to all human pleasure. "Jealousy is a painful passion; yet without some share of it, the agreeable affection of love has difficult to subsist in its full force" (Stroud, 1977). Absence also provides uneasiness to lovers, but "nothing is more favorable to their mutual passion than short intervals of that kind" (Stroud, 1977).

The discussion of aesthetic effect Of Tragedy begins from Aristotle. In Poetics, Aristotle holds that tragedy can supply us with a special pleasure, "a pleasure springing from pity and fear via mimesis" (Stroud, 1977). Hume follows Aristotle in his discussion Of Tragedy and goes further to illustrate the interaction and passions of different qualities from the perspective of mental process, which is original in the western study Of Tragedy.

\section{Conclusion}

As an empiricist, Hume explores the essence of beauty based on experience and observations. He regards the natural capacity of taste as fundamental to the human ability to make moral and aesthetic judgments. By equating perception of beauty with the experience of the sentiment, he defines beauty as an original, simple impression of the mind. Hume also argues that the spectator is aware that he is witnessing a dramatic performance. There is pleasure in realizing that the terrible events that are being shown are actually fiction. Furthermore, Hume laid down rules for educating people in taste and correct conduct.

In short, Hume's aesthetic theory is intimately connected to his moral philosophy and theories of human thought and emotion.

\section{References}

Cooper, D. E. (1997). Aesthetics: The classic readings. Oxford: Blackwell Publishing.

Costelloe, T. (2013). The British aesthetic tradition: From Shaftesbury to Wittgenstein. Cambridge: Cambridge University Press.

Green, T. H., \& Grose, T. H. (Ed.). (1874). The philosophical works of David Hume. London: Longman, Green.

Hume, D. (1985). A treatise of Human Nature. London: Penguin Classics. 
Hume, D. (1957). An inquiry concerning the principles of morals. Indianapolis, IN: The Bobbs-Merrill Company, Inc. Lenz, J. W. (1982). Of the standard of taste and other essays. Indianapolis, IN: The Bobbs-Merrill Company, Inc. Mackie, J. L. (1980). Hume's moral theory. London: Routledge \& Kegan Paul Ltd.

Savile, A. (1982). The test of time: An essay in philosophical aesthetics. Oxford: Clarendon Press.

Stroud, B. (1977). Hume. London: Routledge \& Kegan Paul Ltd.

休谟 (2001). 《道德原则研究》。北京: 商务印书馆。

休谟 (1983). 《人性论》。北京: 商务印书馆。

喻青 (2002). 《休谟经典文存》。上海: 上海大学出版社。

张中载 (2000). 《西方古典文论选读》。北京: 外语教学与研究出版社。

周晓亮 (1999).《休谟哲学研究》。北京: 人民出版社。 